\title{
Using satellite telemetry and environmental niche modelling to inform conservation targets for a long-distance migratory raptor in its wintering grounds
}

\author{
Ruben Limiñana, Beatriz Arroyo, Julien Terraube \\ Michael McGrady and François Mougeot
}

\begin{abstract}
Understanding the ecology of migratory birds during the non-breeding season is necessary for ensuring their conservation. Using satellite telemetry data we describe winter ranging behaviour and movements of pallid harriers Circus macrourus that bred in Kazakhstan. We developed an ecological niche model for the species in Africa, to identify the most suitable wintering areas for pallid harriers and the importance of habitat in determining the location of those areas. We also assessed how well represented suitable areas are in the network of protected areas. Individual harriers showed relatively high fidelity to wintering areas but with potential for interannual changes. The ecological niche model highlighted the importance of open habitats with natural vegetation. Most suitable areas for the species were located in eastern Africa. Suitable areas had a patchy distribution but were relatively well included in the network of protected areas. The preferential use of habitats with natural vegetation by wintering pallid harriers and the patchiness of the most suitable areas highlight the harrier's vulnerability to land-use changes and the associated loss of natural vegetation in Africa. Conservation of harriers could be enhanced by preserving natural grasslands within protected areas and improving habitat management in the humaninfluenced portions of the species' core wintering areas.
\end{abstract}

Keywords Circus macrourus, Ethiopia, Maxent, pallid harrier, protected areas, Sahel belt, winter habitat use

\section{Introduction}

$\mathrm{M}$ igratory birds can be affected by threats occurring on breeding and non-breeding grounds (Newton, 2004),

RUBEN LimiÑANA and BEATRIZ ARroyo Instituto de Investigación en Recursos Cinegéticos (IREC; CSIC-UCLM-JCCM), Ciudad Real, Spain

Julien Terraube Department of Biology, University of Turku, Turku, Finland Michael McGRADY* Natural Research, Banchory, UK

FranCoIS Mougeot (Corresponding author) Estación Experimental de Zonas Áridas (EEZA-CSIC), Carretera de Sacramento, s/n. La Cañada de San Urbano, E-04120 Almería, Spain. E-mail francois.mougeot@eeza.csic.es

*Current address: Am Rosenhügel 59, 3500 Krems, Austria

Received 27 November 2012. Revision requested 7 March 2013 Accepted 16 July 2013. First published online 17 July 2014. and carry-over effects of winter conditions may influence their success or survival in subsequent breeding seasons (Newton, 2008; Zwarts et al., 2009). There is thus a growing recognition of the need for a better understanding of the ecology of migratory birds during the non-breeding period (Martin et al., 2007).

Defining the ranging behaviour, habitat use or environmental variables that determine the distribution of migratory bird species outside the breeding season is essential to define meaningful conservation actions (Martin et al., 2007). Areas suitable for migrants during non-breeding are sometimes identified based on empirical information (such as local censuses) but can be identified also through modelling (Beresford et al., 2011; Jiguet et al., 2011).

The pallid harrier Circus macrourus is a medium-sized migratory raptor. Its main breeding populations are in the steppes of Asiatic Russia, Kazakhstan and north-west China, and the majority of birds spend the non-breeding period in sub-Saharan Africa or the Indian subcontinent (del Hoyo et al., 1994). The pallid harrier is included in Annex I of the European Birds Directive (2009/147/CE), and its habitats throughout its distribution should be protected to ensure its persistence. The species is categorized as Near Threatened on the IUCN Red List (BirdLife International, 2013) as a result of population declines. These may be linked to effects during the breeding season but negative effects such as habitat loss and degradation in wintering areas may be equally important (Thiollay, 2006). Analysis of the pallid harrier's habitat requirements in its African and Indian non-breeding range is considered a priority for conservation (BirdLife International, 2012).

The migratory routes and wintering range of pallid harriers breeding in Kazakhstan and adjacent areas of Russia have been described using satellite telemetry (Terraube et al., 2012). Buij et al. (2012) showed that pallid harriers wintering in northern Cameroon preferentially used rice fields and flooded grasslands, with evidence of sexual differences in habitat use when foraging. However, general knowledge about the ranging behaviour and habitat use of this species during the non-breeding period is lacking and this impedes conservation.

We describe movements by individual harriers during winter, and interannual variation in their winter range. We develop an ecological niche model (based on 
TABLE 1 Data on wintering events of six adult satellite-tracked pallid harriers Circus macrourus, with bird identification number, sex, wintering period, number of wintering locations recorded, size of wintering grounds, and country. Wintering events for which the transmitter stopped working during the wintering season are considered incomplete.

\begin{tabular}{|c|c|c|c|c|c|}
\hline Wintering period & $\begin{array}{l}\text { Wintering } \\
\text { locations }\end{array}$ & $\begin{array}{l}\text { Size of wintering } \\
\text { grounds }\left(\mathrm{km}^{2}\right)\end{array}$ & Country (geographical coordinates) & $\begin{array}{l}\text { Complete/ } \\
\text { incomplete }\end{array}$ & $\begin{array}{l}\text { Wintering } \\
\text { event }\end{array}$ \\
\hline \multicolumn{6}{|l|}{ Bird no. 42670 (male) } \\
\hline 27 Oct. 2008-29 Mar. 2009 & 55 & 158.87 & Níger $\left(14.69^{\circ} \mathrm{N} 8.67^{\circ} \mathrm{E}\right)$ & Complete & 1 \\
\hline \multicolumn{6}{|l|}{ Bird no. 42674 (female) } \\
\hline 17 Nov. 2008-15 Mar. 2009 & 21 & 448.23 & Burkina Faso $\left(14.54^{\circ} \mathrm{N} 0.02^{\circ} \mathrm{E}\right)$ & Complete & 2 \\
\hline \multicolumn{6}{|l|}{ Bird no. 42675 (female) } \\
\hline 19 Nov. 2007-21 Mar. 2008 & 39 & $241,409.89$ & Sudan $\left(16.37^{\circ} \mathrm{N} 34.61^{\circ} \mathrm{E}\right.$ and $\left.9.43^{\circ} \mathrm{N} 29.39^{\circ} \mathrm{E}\right)$ & Complete & 3 \\
\hline 6 Nov. 2008-28 Mar. 2009 & 87 & 662.49 & $\operatorname{Sudan}\left(9.37^{\circ} \mathrm{N} 29.01^{\circ} \mathrm{E}\right)$ & Complete & 4 \\
\hline \multicolumn{6}{|l|}{ Bird no. 82826 (female) } \\
\hline 31 Oct. 2008-9 Dec. 2008 & 65 & 52.83 & Ethiopia $\left(12.57^{\circ} \mathrm{N} 39.27^{\circ} \mathrm{E}\right)$ & Incomplete & 5 \\
\hline \multicolumn{6}{|l|}{ Bird no. 82827 (male) } \\
\hline 30 Oct. $2008-25$ Nov. 2008 & 11 & 130.67 & Sudan $\left(9.11^{\circ} \mathrm{N} 32.35^{\circ} \mathrm{E}\right)$ & Incomplete & 6 \\
\hline \multicolumn{6}{|l|}{ Bird no. 82829 (female) } \\
\hline 28 Oct. $2008-22$ Mar. 2009 & 279 & 18.89 & Ethiopia $\left(7.23^{\circ} \mathrm{N} 40.01^{\circ} \mathrm{E}\right)$ & Complete & 7 \\
\hline 19 Oct. 2009-21 Mar. 2010 & 245 & 40.33 & Ethiopia $\left(7.23^{\circ} \mathrm{N} 40.01^{\circ} \mathrm{E}\right)$ & Complete & 8 \\
\hline 31 Oct. 2010-27 Mar. 2011 & 38 & $22,158.41$ & Syria $\left(35.17^{\circ} \mathrm{N} 40.39^{\circ} \mathrm{E}\right)$ & Complete & 9 \\
\hline
\end{tabular}

topographic, habitat and climate variables) to identify suitable wintering areas for pallid harriers, and assess the importance of habitat in determining that niche. Finally, we analyse the importance of existing protected areas for pallid harriers and discuss the implications of our findings for the conservation of pallid harriers globally.

\section{Methods}

\section{Tagging and tracking data}

Nine adult pallid harriers (four males, five females) were trapped and fitted with solar-powered satellite-received transmitters (PTTs; North Star Science and Technology, King George, USA) during the 2007 and 2008 breeding seasons in the Naurzum and Turgai regions of north-central Kazakhstan (see Terraube et al., 2012, for details of capture and tagging).

Birds were tracked using the Argos system of satellites (CLS, Ramonville Saint-Agne, France), which estimates locations of transmitters and calculates an error distribution for each estimate, the location class (LC). We used highquality locations ( $\mathrm{LC}_{3}, 2$ and 1 ) for our analyses. Locations with LC 3, 2 and 1 have nominal errors up to 150,350 and $1,000 \mathrm{~m}$, respectively. Of the nine tagged birds, three stopped transmitting shortly after tagging. Of the remaining six birds, four were tracked for all (one male and one female) or part (one male and one female) of the non-breeding season (hereafter called winter) subsequent to trapping; one female was tracked for two consecutive winters and one for three consecutive winters (Table 1). We use data from the latter two birds to describe interannual variations in wintering areas. A wintering event refers to wintering locations for each bird and wintering season.

\section{Movements of pallid harriers during winter}

During migration, pallid harriers make stopovers that can last up to 15 days (Terraube, 2010). We defined the wintering season (to differentiate from migratory locations) based on when birds settled in an area (i.e. moved $<20 \mathrm{~km}$ per day) for $>15$ days. We recorded a total of 840 wintering locations from six tracked harriers, of which $64 \%$ had a nominal precision of $<350 \mathrm{~m}$ (i.e. had LCs of 3 or 2 ); the number of locations for each wintering event was 11-279 (Table 1). We calculated the home range for each wintering event as the 95\% fixed kernel and used the least squares cross-validation procedure to set the smoothing parameter $(H)$, using the Animal Movement extension (Hooge \& Eichenlaub, 1997) for ArcView v.3.2 (ESRI, Redlands, USA). The size of each kernel polygon was calculated based on a cylindrical equalarea projection of the Earth, using the Projector! extension for ArcView.

\section{Habitat use and ecological niche model}

We used the global land cover map GlobCover v. 2.3 (ESA, 2010) to map habitat. GlobCover uses satellite image data from 2009 to map land cover in raster format at $300 \mathrm{~m}$ resolution. We rescaled this map by overlaying it with a grid (2.5 arc-min pixel size, i.e. $4.5 \times 4.5 \mathrm{~km})$ and assigning a habitat descriptor to each cell, based on the main cover type (mode of pixels) within. This analytical scale matches the nominal error of the satellite locations and has been used in 
TABLE 2 Variables used in the ecological niche model.

\begin{tabular}{|c|c|}
\hline Variable & Source \\
\hline $\begin{array}{l}\text { Habitat variables: } \\
\text { See Table } 3\end{array}$ & GlobCover (ESA, 2010) \\
\hline $\begin{array}{l}\text { Climatic variables: } \\
\text { Mean annual temperature }\left({ }^{\circ} \mathrm{C}\right) \text {; temperature seasonality }(\mathrm{SD} \text { of monthly } \\
\text { mean temperatures); max. temperature of warmest month }\left({ }^{\circ} \mathrm{C}\right) \text {; min. } \\
\text { temperature of coldest month }\left({ }^{\circ} \mathrm{C}\right) \text {; annual precipitation }(\mathrm{mm}) \text {; precipitation } \\
\text { of driest month }(\mathrm{mm}) \text {; precipitation of wettest month }(\mathrm{mm}) \text {; } \\
\text { precipitation seasonality (coefficient of variation of monthly precipitation) }\end{array}$ & BioClim (Hijmans et al., 2005) \\
\hline $\begin{array}{l}\text { Topographical variables: } \\
\text { Slope }\left(\text { degrees) }{ }^{1} \text {; aspect (continuous variable between } 0 \text { and } 360^{\circ}\right)^{2}\end{array}$ & $\begin{array}{l}\text { Derived from digital elevation model of } \\
\text { BioClim (Hijmans et al., 2005) }\end{array}$ \\
\hline Distance to rivers $(\mathrm{km})$ & Shapefile of rivers of Africa (UNEP/FAO, 2013) \\
\hline
\end{tabular}

similar studies (Jiguet et al., 2011; Limiñana et al., 2012a). The habitat associated with each harrier location was that of the cell in which the location occurred. We calculated the proportions of locations in each habitat type for every wintering event and used $\chi^{2}$ tests to evaluate differences in habitat use between individuals or wintering events.

Given the overall extent of the wintering range (see Results and also Terraube et al., 2012) and the small number of tracked birds, it was not possible to study habitat selection by comparing the habitat where harriers were located with habitat at random points, because random locations would probably not fall within areas suitable for harriers. Instead, we modelled the harrier's ecological niche and assessed the importance of habitats in determining that niche, using Maxent, which does not require true-absence data to develop a predictive model (Phillips et al., 2006; Elith et al., 2011). The evaluation of distribution models on the basis of tracking data, even when based on a small number of individuals, has been a useful approach for other species (Wisz et al., 2008; Monterroso et al., 2009; Gschweng et al., 2012; Limiñana et al., 2012a). Key assumptions for presence-only models are that sampling is either random or representative throughout the landscape and that detection probability is constant across sites (Yackulic et al., 2012). The latter is clearly met by satellite tracking. In relation to the former, our assumption is that trapped adults represent a random sample of the breeding population and thus of wintering locations of birds from the core breeding distribution area. Sampling bias would also arise if some individuals contributed more than others to the data set. This issue can be addressed by random sampling to homogenize the contributions made by all individuals (Gschweng et al., 2012; Limiñana et al., 2012a). To do this we randomly selected two locations per month (to accommodate possible variation over time) for each tracked bird during winter; for the two birds with data from two consecutive wintering seasons we pooled data from both wintering events (i.e. only two locations per calendar month were used, irrespective of wintering event). One of the birds, having spent two consecutive winters in Ethiopia, spent its third winter in the Middle East (see Results). Data from this last wintering season were not used for the ecological niche model, which we developed only for the region of Africa bounded by latitude $5-20^{\circ} \mathrm{N}$ and longitude $-19-52^{\circ} \mathrm{E}$. Overall, 52 locations contributed to the development of the model (30 of which had a precision of $<350 \mathrm{~m}$ ), with the number of locations per bird in the range $2-12$. We set a random selection of $20 \%$ of these occurrence data to test the model.

As predictive variables of the ecological niche, we used 12 environmental grid layers at a resolution of 2.5 arc-min $(4.5 \times 4.5 \mathrm{~km})$ within the above-mentioned region. These included the habitat layer, eight climatic variables, two topographical variables, and distance to rivers (Table 2). The latter was included because exploration of locations with Google Earth (Google Inc., Mountain View, USA) revealed that many locations during the wintering season were close to rivers. Maxent produces a logistic output for every grid cell, ranging between $o$ and 1, reflecting relative occupancy probability. Following Limiñana et al. (2012a), we considered cells for which this value was $0.5-0.75$ as 'suitable' and those for which raw output was $>0.75$ as 'very suitable'. We analysed which habitat categories contributed most to the presence of harriers within the modelled region, taking into account the possible correlations of habitat with other predictive variables (as defined in the Maxent results).

\section{Pallid harriers and protected areas}

We assessed the extent to which suitable and very suitable areas for the species overlapped with protected areas, based on nationally recognized protected areas listed in the 2010 
TABLE 3 Percentages of satellite telemetry fixes in the different habitats used by pallid harriers during the wintering season. The numbering of wintering events is the same as in Table 1. Mean values (for all wintering events) of the percentage of fixes in each habitat type are also presented.

\begin{tabular}{|c|c|c|c|c|c|c|c|c|c|c|}
\hline \multirow[b]{2}{*}{ Habitat } & \multicolumn{9}{|c|}{ Wintering event } & \multirow[b]{2}{*}{ Mean } \\
\hline & 1 & 2 & 3 & 4 & 5 & 6 & 7 & 8 & 9 & \\
\hline $\begin{array}{l}\text { Mosaic cropland }(50-70 \%) / \text { natural vegetation } \\
\text { (grassland/shrubland/forest) }(20-50 \%)\end{array}$ & & & & 1.15 & & 90.91 & 65.95 & 65.71 & 39.47 & 44.17 \\
\hline Mosaic forest or shrubland (50-70\%)/grassland (20-50\%) & & 4.76 & 38.46 & 65.52 & 81.54 & 9.09 & 34.05 & 34.29 & & 36.43 \\
\hline $\begin{array}{l}\text { Closed to open }(>15 \%) \text { (broadleaved or needleleaved, } \\
\text { evergreen or deciduous) shrubland }(<5 \mathrm{~m})\end{array}$ & & & 33.33 & 33.33 & 18.46 & & & & & 6.43 \\
\hline $\begin{array}{l}\text { Closed to open }(>15 \%) \text { herbaceous vegetation } \\
\text { (grassland, savannah or lichens/mosses) }\end{array}$ & 12.73 & 90.48 & & & & & & & & 3.10 \\
\hline Sparse $(<15 \%)$ vegetation & & 4.76 & & & & & & & 47.37 & 2.26 \\
\hline Bare areas & 87.27 & & 28.21 & & & & & & 13.16 & 7.62 \\
\hline
\end{tabular}

World Database on Protected Areas (UNEP-WCMC, 2010). When the boundaries of a protected area were not available but its coordinates and extension were indicated, we generated a circular buffer around the given coordinates, the radius of which encompassed the nominal boundaries of the protected area, and used the resulting circular area in our analyses (Soutullo et al., 2008; Limiñana et al., 2012a).

\section{Results}

\section{Wintering areas and home ranges}

Tracked harriers wintered within a relatively narrow latitudinal band but showed a wide longitudinal range (Table 1; Fig 1). Four wintered in eastern Africa (Sudan and Ethiopia) and two were tracked to western Africa (Burkina Faso and Niger).

Data from the two birds that were tracked for more than one season suggest that winter site fidelity is variable. One bird (42675) spent the first tracked winter in two distinct areas c. $1,000 \mathrm{~km}$ apart, spending 1 month c. $250 \mathrm{~km}$ north-east of Khartoum (Sudan) and then moving south to an area near the border between Sudan and South Sudan, where it spent c. 3 months. Therefore, the overall home range was large (Table 1) but ranges in each sub-area were much smaller (560 and $1,063 \mathrm{~km}^{2}$ for the first and second areas, respectively). The following winter this bird migrated directly to the southern home range of the previous year, where it spent the whole winter in an area of $663 \mathrm{~km}^{2}$ (Table 1). Another bird (82829) spent the first two tracked winters in a small area in Ethiopia (Table 1) but in its third tracked winter (2010-2011) it settled in Syria, along the Euphrates River (an area along its autumn migratory route during the previous 2 years). It stayed there for 4 months and ranged over a larger area than that used in previous winters in Ethiopia (Table 1). Although a fourth year of wintering was not recorded for this bird because of a
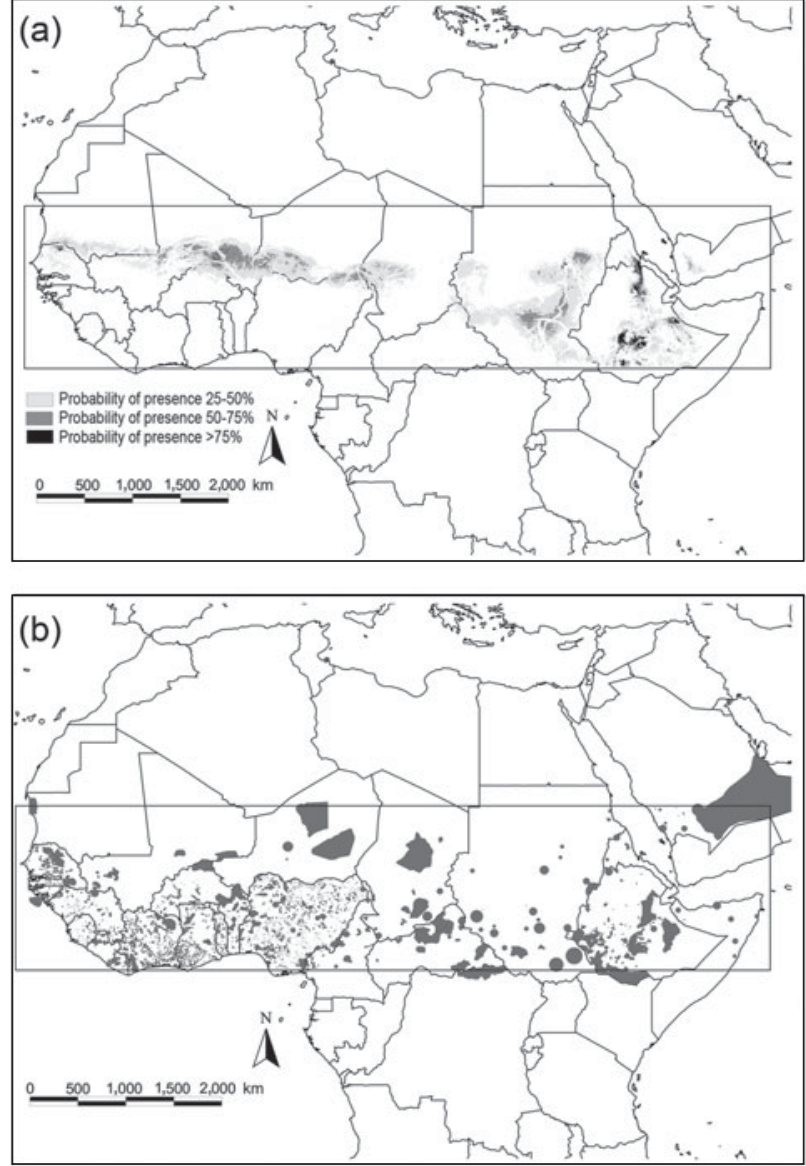

FIG. 1 (a) Ecological niche model results for the pallid harrier Circus macrourus across the Sahel belt in Africa (indicated by the rectangle). Probability of presence in $4.5 \times 4.5 \mathrm{~km}$ cells is indicated according to a three-category scale (25-50, 50-75 and $>_{75 \%}$ ). (b) Existing protected areas in and around the Sahel belt (UNEP-WCMC, 2010).

cessation of transmissions, we know that it visited and bypassed this Syrian wintering location during migration, after which it travelled into Saudi Arabia and then moved northwards; its last known location was c. $400 \mathrm{~km}$ south of 


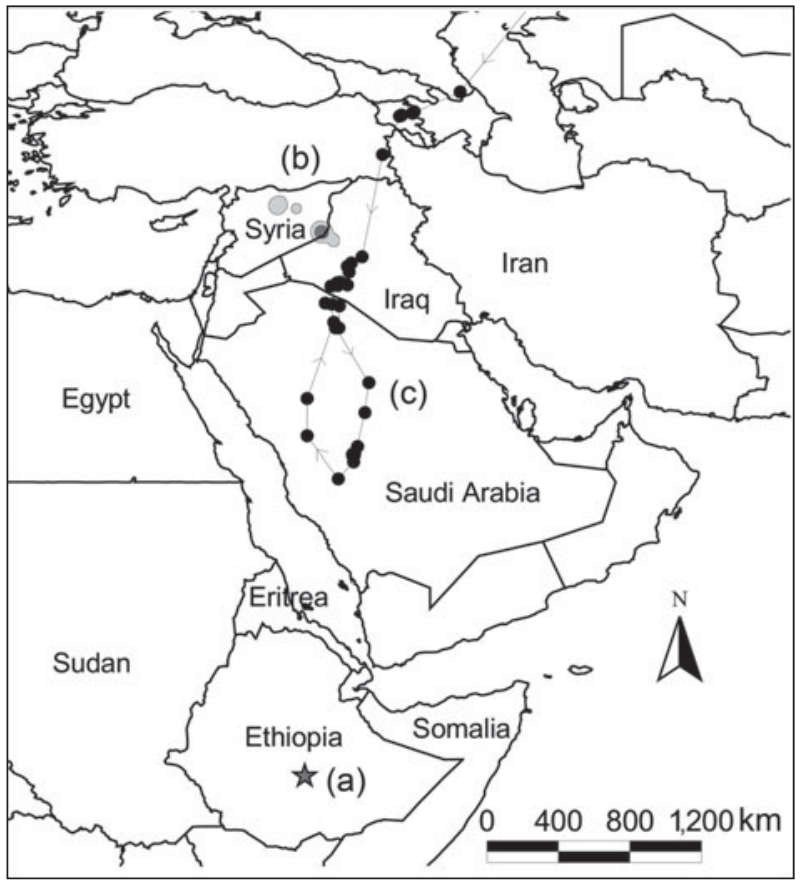

FIG. 2 Wintering areas of pallid harrier number 82829 . The bird spent two consecutive winters, 2008/2009 and 2009/2010, in Ethiopia (depicted as a star because of the small home range; Table 1). The following winter it remained in Syria (95\% fixed kernel in dark grey and 50\% fixed kernel in light grey are illustrated). Its autumn migration movements in 2011 were recorded until the satellite transmitter stopped working. (a) Wintering area in 2008/2009 and 2009/2010; (b) wintering area in 2010/2011; (c) movements prior to wintering 2011/2012.

the area used the previous winter in Syria (Fig. 2). Individual home ranges of other tracked harriers during the nonbreeding season were relatively small $\left(19-448 \mathrm{~km}^{2}\right.$; Table 1$)$.

\section{Habitat use}

During the wintering season harriers used mostly areas of natural vegetation (mosaics of forest/shrubland and grassland; $36 \%$ of locations) or mosaics of cropland and natural vegetation ( $44 \%$ of locations). Other habitats accounted for $<10 \%$ of the recorded locations (Table 3 ). Habitat use differed between individuals $\left(\chi_{40}^{2}=1,928.17, \mathrm{P}<0.001\right)$. Some harriers used mainly cropland mosaics $(82827$ and also 82829 when it wintered in Africa), whereas other birds used different types of natural vegetation (including forest, shrubland or grassland; Table 3). For bird 82829 there were also significant differences in habitat use between wintering events $\left(\chi_{6}^{2}=333.99, \mathrm{P}<0.001\right)$; whereas it used mainly mosaics of cropland and natural vegetation in the Sahel, it used mainly sparse vegetation along the Euphrates River in Syria (Table 3). A more detailed inspection of those data, using Google Earth, indicated that the bird may have taken advantage of irrigated croplands along the Euphrates River, which were not identified as such by GlobCover.
TABLE 4 Contribution of each environmental variable, in decreasing order, to the ecological niche model for wintering pallid harriers around the Sahel belt.

\begin{tabular}{ll}
\hline Variable & \% contribution \\
\hline Precipitation of wettest month & 34.1 \\
Annual mean temperature & 21 \\
Habitat & 14.5 \\
Min. temperature of coldest month & 7 \\
Slope & 6.1 \\
Distance to rivers & 5.5 \\
Precipitation of driest month & 3.5 \\
Annual precipitation & 2.5 \\
Temperature seasonality & 2.2 \\
Precipitation seasonality & 1.7 \\
Aspect & 1.4 \\
Max. temperature of the warmest month & 0.4 \\
\hline
\end{tabular}

\section{Ecological niche model of wintering pallid harriers} in Africa

After climatological variables, habitat was one of the main factors that influenced harrier occurrence (Table 4). Maxent results showed that, after controlling for correlations of habitat with other predictive variables, mosaics of forest/ shrubland and grassland, mosaics of cropland and forest/ shrubland/grassland and closed-to-open herbaceous vegetation (in that order) contributed most to explaining harrier occurrence.

Suitable areas for this species in the modelled region covered 289,249 $\mathrm{km}^{2}$ and occurred both in the eastern and western parts of the Sahel, whereas very suitable areas covered only $26,752 \mathrm{~km}^{2}$ and were located mainly in eastern Sahel and central Ethiopia/Eritrea (Fig. 1a). The existing network of protected areas in the study region includes 25.4 and $14.1 \%$ of the very suitable and suitable areas, respectively. Protected areas that were very suitable for harriers were mainly within the Oromia region of Ethiopia (Fig. 1a); some suitable areas in central Sahel were also within reserves (Fig. 1b). Locations of two of the tracked birds were recorded within protected areas: bird 42674 in northern Burkina Faso (Sahel Reserve; seven of 21 locations recorded) and bird 82829 in Ethiopia (Bale Mountains National Park; 24 of 279 locations recorded).

\section{Discussion}

\section{Movements during and between winters}

We observed a relatively high fidelity to wintering areas, with the possibility of large interannual variations in the location of wintering areas, in this nomadic long-distance migratory raptor. Although based on a small sample, fidelity to wintering grounds appeared to be higher than 
fidelity to breeding grounds (distance between locations

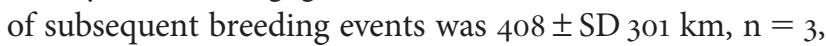
range $0-834 \mathrm{~km}$; Terraube, 2010). Similar results were obtained for snowy owls Bubo scandiacus, which are also nomadic (although their nomadic movements are shorter than those of the pallid harrier) and faithful to wintering areas (Therrien et al., 2011). Once settled in their African quarters, pallid harriers move mostly short distances, resulting in smaller home ranges than for the closely related Montagu's harrier Circus pygargus, which also winters in the Sahel (Limiñana et al., 2012a). This may be related to differences in winter diets. The pallid harrier is a smallrodent specialist during breeding (Terraube et al., 2011) and small mammals and passerines contribute a large proportion of its total biomass consumption in winter (Buij et al., 2012). Hence, if pallid harriers reach an area of high vertebrate prey abundance in winter they may settle and remain there. During winter, Montagu's harriers feed on grasshoppers and locusts (Orthoptera), and individuals may move large distances in search of these prey (Mullié, 2009; Trierweiler \& Koks, 2009; Limiñana et al., 2012b).

Our results also show the potential for variation from this pattern among and within individual pallid harriers. One of the birds spent two consecutive winters in the same area in Ethiopia and then spent the subsequent winter in an area in Syria located along the pathway used in previous migrations (Terraube et al., 2012). Moreover, in the subsequent autumn migration this bird was heading towards Africa (possibly its wintering areas in previous years in Ethiopia) but turned back northwards just before crossing the Red Sea; the transmitter stopped working when the bird was nearing its previous wintering area in Syria (Fig. 2). This shift in the location of the wintering grounds could be associated with a nomadic strategy that allows pallid harriers to exploit unpredictable resources encountered during their dispersion and migration movements. Nomadic species may be particularly efficient in making use of past experience and spatial memory to track and exploit available resources (Bennetts \& Kitchens, 2000). If prey is available, staying in areas visited in previous years may be a better option (in terms of enhancing survival) than attempting to cross harsh areas or ecological barriers to reach traditional wintering grounds (Strandberg et al., 2010; Mellone et al., 2011). Individual variations in migration and wintering behaviour probably depend on resource distribution, as well as experience and condition (e.g. energy stores, breeding status, predation risk, prior knowledge), and even sex (Buij et al., 2012).

\section{Wintering habitats and conservation}

During winter, pallid harriers depend more on habitats that include at least some natural vegetation (i.e. grassland, shrubland or open forest) than the closely related Montagu's harrier, which mainly uses cropland during winter (Limiñana et al., 2012a). In addition, and to a greater extent than for Montagu's harriers (Limiñana et al., 2012a), the most suitable areas for wintering pallid harriers had a relatively patchy distribution and were mostly located in the eastern Sahel and Ethiopia. This may be, in part, because areas of natural vegetation (dry grasslands) are more extensive in this region than in the western Sahel (Zwarts et al., 2009). These areas may hold more small mammals, which are important prey for pallid harriers. Small rodents are more abundant in eastern Africa, particularly in the grasslands of the Ethiopian high plateau (Datiko et al., 2007; Workeneh et al., 2011), than along the Sahelian belt (Thiollay, 1989; Simmons, 2000). The association of pallid harriers with habitats other than cropland, and the patchiness of the best wintering areas highlight the vulnerability of this species to the loss of good wintering habitats. The system of grasslands and thorn forests commonly used as foraging and roosting habitat by wintering pallid harriers, according to our results, is under threat in Africa. Habitat quality is declining, probably as a result of the widespread conversion of grassland into cropland, excess harvesting of trees in some areas, overgrazing, and shrub encroachment in less favourable grasslands as a consequence of changes in pastoral activities (particularly the loss of nomadic livestock herding; Western et al., 2009; Zwarts et al., 2009; Donald et al., 2010). Increasing anthropic pressure (through human population growth) is probably a significant cause of loss of areas of natural vegetation in Ethiopia (Meshesha et al., 2012), where most of the highly suitable areas for the species remain. Nomadism may enable pallid harriers to look for alternative areas but if potentially suitable areas are fragmented and far apart this may constitute a cost for the species (Bowling et al., 2012).

Our results also suggest that the distribution of pallid harriers in Africa during winter is associated with climatic variables. Thus, changes in the general patterns of temperature and rainfall could affect this species' choice of wintering areas. Changes in rainfall patterns in the Sahel can affect the migration performance and population trends of trans-Saharan migratory birds (Saino et al., 2007; Newton, 2008; Mihoub et al., 2010) and other prey. For example, orthopteran and passerine abundances in Africa depend on the amount of rainfall in June-September (Morel \& Morel, 1978; Zwarts et al., 2009), before the arrival of wintering Palaearctic raptors. Therefore, climate change may act synergistically with land-use changes to negatively affect migratory bird populations (Hein, 2006; Hein \& de Ridder, 2006).

The ecological niche model highlighted the greater importance of eastern compared to western areas in Africa for the pallid harrier. This is in agreement with Thiollay (1977, 1989), who reported increasing abundance along a 
west-to-east gradient from Senegal to Chad. The model also suggested that the most suitable areas for pallid harriers within the studied region are relatively well represented within the existing network of protected areas, at least when compared with Montagu's harrier and its preferred habitat in the same region (Limiñana et al., 2012a). The model highlighted the importance of Bale Mountains National Park and other surrounding protected areas in the Oromia region of Ethiopia. This is consistent with pallid harriers favouring areas of natural vegetation during winter, which are more likely to be represented within protected areas than farmland (Beresford et al., 2011). However, grasslands, which are important for wintering pallid harriers (as shown here), are currently underrepresented within protected areas compared to other natural-vegetation habitats (Lee \& Jetz, 2008; Soutullo et al., 2008; Buchanan et al., 2009), and therefore increasing the area of protected grasslands could benefit the conservation of the species.

\section{Perspectives and limitations}

The results presented here should be considered in light of the low number of birds tracked and the fact that some tracked birds contributed few locations to the model. Factors such as the individual variation in wintering areas and ranging behaviour, habitat use, wintering site fidelity, sex, spatial scale and even timing of transmissions may have influenced the results of the ecological niche model. Hence, our results should be regarded as a first step in understanding the needs of this species in winter, and more data are needed to improve precision. Ideally, model predictions should be validated by field observations.

Further research is also needed to identify the most profitable foraging habitats for pallid harriers at local scales, as done by Buij et al. (2012). Detailed field studies on diet, prey (passerine birds, grasshoppers and small rodents) abundance and foraging success in different habitats (e.g. grassland, cropland, shrubland) and areas (western vs eastern Africa) would be valuable, as would an assessment of the spatial variation in trophic diversity along the longitudinal range of this species' distribution in winter. Combining this ecological information with estimates of recent changes in land use could result in more effective management of the wintering habitats of harriers in protected areas.

\section{Acknowledgements}

We thank Jesus T. Garcia, Bob Stakim, Evgeny and Alexander Bragin, Todd Katzner, and Alexei Timoshenko for help during the fieldwork in Kazakhstan, Ewan Weston for technical support, the late Mike Madders for encouragement and inspiration throughout the project, and Natural Research Ltd for funding. R. Limiñana benefited from a postdoctoral grant (reference 10/12-C) co-funded by 'Consejería de Educación y Ciencia' and the European Social Fund. Rob Simmons and an anonymous referee helped improve the article.

\section{References}

Bennetts, R.E. \& Kitchens, W.M. (2000) Factors influencing movement probabilities of a nomadic food specialist: proximate foraging benefits or ultimate gains from exploration? Oikos, 91, 459-467.

Beresford, A.E., Buchanan, G.M., Donald, P.F., Butchart, S.H.M., Fishpool, L.D.C. \& Rondinini, C. (2011) Poor overlap between the distribution of protected areas and globally threatened birds in Africa. Animal Conservation, 14, 99-107.

Birdlife International (2012) Species Factsheet: Pallid Harrier Circus macrourus. Http://www.birdlife.org/datazone/ speciesfactsheet.php?id=3409 [accessed 23 March 2012].

BirdLife International (2013) Circus macrourus. In IUCN Red List of Threatened Species v.2013.2. Http://www.iucnredlist.org [accessed 4 February 2014].

Bowling, A.C., Martin, J. \& Kitchens, W.M. (2012) The effect of changes in habitat conditions on the movement of juvenile snail kites Rostrhamus sociabilis. Ibis, 154, 554-565.

Buchanan, G.M., Donald, P.F., Fishpool, L.D.C., Arinaitwe, J.A., Balman, M. \& Mayaux, P. (2009) An assessment of land cover and threats in Important Bird Areas in Africa. Bird Conservation International, 19, 49-61.

Buij, R., van Der Goes, D., De Iongh, H.H., Gagare, S., Haccou, P., Komdeur, J. \& de Snoo, G. (2012) Interspecific and intraspecific differences in habitat use and their conservation implications for Palaearctic harriers on Sahelian wintering grounds. Ibis, 154, 96-110.

Datiko, D., Bekele, A. \& Belay, G. (2007) Species composition, distribution and habitat association of rodents from Arbaminch forest and farmlands, Ethiopia. African Journal of Ecology, 45 651-657.

del Hoyo, J., Elliott, A. \& Sargatal, J. (1994) Handbook of the Birds of the World: volume 2. New World Vultures to Guineafowl. Lynx Editions, Barcelona, Spain.

Donald, P.F., Buchanan, G.M., Collar, N.J., Abebe, Y.D., Gabremichael, M.N., Mwangi, M.A.K. et al. (2010) Rapid declines in habitat quality and population size of the liben (Sidamo) lark Heteromirafra sidamoensis necessitate immediate conservation action. Bird Conservation International, 20, 1-12.

Elith, J., Phillips, S.J., Hastie, T., Dudik, M., Chee, Y.E. \& YATES, C.J. (2011) A statistical explanation of MaxEnt for ecologists. Diversity and Distributions, 17, 43-57.

ESA (European Space Agency) (2010) GlobCover. Http://due.esrin. esa.int/globcover/ [accessed 4 February 2014].

Gschweng, M., Kalko, E.K.V., Berthold, P., Fiedler, W. \& FAHR, J. (2012) Multi-temporal distribution modeling with satellite tracking data: predicting responses of a long-distance migrant to changing environmental conditions. Journal of Applied Ecology, 49, 803-813.

HEIN, L. (2006) The impacts of grazing and rainfall variability on the dynamics of a Sahelian rangeland. Journal of Arid Environments, $64,488-504$ 
Hein, L. \& de Ridder, N. (2006) Desertification in the Sahel: a reinterpretation. Global Change Biology, 12, 751-758.

Hijmans, R.J., Cameron, S.E., Parra, J.L., Jones, P.G. \& JARVIS, A. (2005) Very high resolution interpolated climate surfaces for global land areas. International Journal of Climatology, 25, 1965-1978.

Hooge, P.N. \& Eichenlaub, B. (1997) Animal Movement Extension to ArcView. U.S. Geological Survey, Anchorage, USA.

Jiguet, F., Barbet-Massin, M. \& Chevallier, D. (2011) Predictive distribution models applied to satellite tracks: modelling the western African winter range of European migrant black storks Ciconia nigra. Journal of Ornithology, 152, 111-118.

Lee, T.M. \& Jetz, W. (2008) Future battlegrounds for conservation under global change. Proceedings of the Royal Society of London, Series B, 275, 1261-1270.

Limiñana, R., Soutullo, A., Arroyo, B. \& Urios, V. (2012a) Protected areas do not fulfil the wintering habitat needs of the trans-Saharan migratory Montagu's harrier. Biological Conservation, 145, 62-69.

Limiñana, R., Soutullo, A., Urios, V. \& Reig-Ferrer, A. (2012b) Migration and wintering areas of adult Montagu's harriers (Circus pygargus) breeding in Spain. Journal of Ornithology, $153,85-93$.

Martin, T.G., Chadès, I., Arcese, P., Marra, P.P., Possingham, H.P. \& Norris, D.R. (2007) Optimal conservation of migratory species. PLoS ONE, 2(8), e751.

Mellone, U., Yánez, B., Limiñana, R., Román-Muñoz, A., Pavón, D., GonzÁlez, J.M. et al. (2011) Summer staging areas of non-breeding short-toed snake eagles Circaetus gallicus. Bird Study, $58,516-521$.

Meshesha, D.T., Tsunekawa, A. \& Tsubo, M. (2012) Continuing land degradation: cause-effect in Ethiopia's central rift valley. Land Degradation \& Development, 23, 130-143.

Minoub, J.-B., Gimenez, O., Pilard, P. \& Sarrazin, F. (2010) Challenging conservation of migratory species: Sahelian rainfalls drive first-year survival of the vulnerable lesser kestrel Falco naumanni. Biological Conservation, 143, 839-847.

Monterroso, P., Brito, J.C., Ferreras, P. \& Alves, P.C. (2009) Spatial ecology of the European wildcat in a Mediterranean ecosystem: dealing with small radio-tracking datasets in species conservation. Journal of Zoology, 279, 27-35.

Morel, G.J. \& Morel, M.-Y. (1978) Recherches écologiques sur une savane sahélienne du Ferlo septentrional, Sénégal. Etude d'une communauté avienne. Cahiers de l'ORSTOM, série Biologie, $13,3-34$.

Mullié, W.C. (2009) Birds, locust and grasshoppers. In Living on the Edge: Wetlands and Birds in a Changing Sahel (eds L. Zwarts, R.G. Bijlsma, J. Van der Kamp \& E. Wymenga), pp. 202-223. KNNV Publishing, Zeist, The Netherlands.

Newton, I. (2004) Population limitation in migrants. Ibis, 146, $197-226$.

Newton, I. (2008) The Migration Ecology of Birds. Academic Press, London, UK

Phillips, S.J., Anderson, R.P. \& Schapire, R.E. (2006) Maximum entropy modeling of species geographic distributions. Ecological Modelling, 190, 231-259.

Pons, X. (2008) MiraMon. Sistema de Información Geográfica y software de Teledetección. Centre de Recerca Ecològica i Aplicacions Forestals, Bellaterra, Spain.

Saino, N., Rubolini, D., Jonzén, N., Ergon, T., Montemaggiori, A., Stenseth, N.C. \& Spina, F. (2007) Temperature and rainfall anomalies in Africa predict timing of spring migration in trans-Saharan migratory birds. Climate Research, 35, 123-134.
Simmons, R. (2000) Harriers of the World. Oxford University Press, Oxford, UK.

Soutullo, A., De Castro, M. \& Urios, V. (2008) Linking political and scientifically derived targets for global biodiversity conservation: implications for the expansion of the global network of protected areas. Diversity and Distributions, 14, 604-613.

Strandberg, R., Klaassen, R.H.G., Hake, M. \& Alerstam, T. (2010) How hazardous is the Sahara Desert crossing for migratory birds? Indications from satellite tracking of raptors. Biology Letters, 6, 297-300

Terraube, J. (2010) Integrating foraging strategies, spatial movement patterns and reproductive success: implication for the conservation of sympatric avian predators. $\mathrm{PhD}$ thesis. Universidad de Castilla-La Mancha, Ciudad Real, Spain.

Terraube, J., Arroyo, B., Madders, M. \& Mougeot, F. (2011) Diet specialisation and foraging efficiency under fluctuating vole abundance: a comparison between generalist and specialist avian predators. Oikos, 120, 234-244.

Terraube, J., Mougeot, F., Cornulier, T., Verma, A., Gavrilov, A. \& Arroyo, B. (2012) Broad wintering range and intercontinental migratory divide within a core population of the near-threatened pallid harrier. Diversity and Distributions, 18, 401-409.

Therrien, J.-F., Gauthier, G. \& Bety, J. (2011) An avian terrestrial predator of the Arctic relies on the marine ecosystem during winter. Journal of Avian Biology, 42, 363-369.

Thiollay, J.-M. (1977) Distribution saisonnière des rapaces diurnes en Afrique Occidentale. Oiseau RFO, 47, 253-294.

Thiollay, J.-M. (1989) Distribution and ecology of Palearctic birds of prey wintering in West and Central Africa. In Raptors in the Modern World (eds B.-U. Meyburg \& R.D. Chancellor), pp. 95-107. WWGBP, Berlin, Germany.

Thiollay, J.-M. (2006) The decline of raptors in West Africa: long-term assessment and the role of protected areas. Ibis, 148, 240-254.

Trierweiler, C. \& Koks, B.J. (2009) Montagu's harrier Circus pygargus. In Living on the Edge: Wetlands and Birds in a Changing Sahel (eds L. Zwarts, R.G. Bijlsma, J. van der Kamp \& E. Wymenga), pp. 312-327. KNNV Publishing, Zeist, The Netherlands.

UneP (United Nations Environment Programme)/FaO (Food and Agriculture Organization of the united NATIONS) (2013) Rivers of Africa. UNEP/FAO Desertification Assessment and Mapping Project. Http://www.fao.org/geonetwork/ srv/en/metadata.show?id=12\&currTab=summary [accessed 7 February 2014].

UneP-WCMC (United Nations Environment Programme World Conservation Monitoring Centre) (2010) 2010 WDPA Annual Release Attribute Data Structure. Http://www.wdpa. org/AnnualRelDataStruc.aspx [accessed 15 June 2012].

Western, D., Groom, R. \& Worden, J. (2009) The impact of subdivision and sedentarization of pastoral lands on wildlife in an African savanna ecosystem. Biological Conservation, 142, $2538-2546$

Wisz, M.S., Hijmans, R.J., Li, J., Peterson, A.T., Graham, C.H., Guisan, A. \& NCEAS Predicting Species Distributions Working Group (2008) Effects of sample size on the performance of species distribution models. Diversity and Distributions, 14, $763-773$.

Workeneh, S., Bekele, A. \& Balakrishnan, M. (2011) Species diversity and abundance of small mammals in Nechisar National Park, Ethiopia. African Journal of Ecology, 50, 102-108.

Yackulic, C.B., Chandler, R., Zipkin, E.F., Royle, J.A., Nichols, J.D., Campbell Grant, E.H. \& Veran, S. (2012) 
Presence-only modeling using MAXENT: when can we trust the inferences? Methods in Ecology and Evolution, 4, 236-243.

Zwarts, L., Bijlsma, R.G., van Der Kamp, J. \& Wymenga, E. (2009) Living on the Edge: Wetlands and Birds in a Changing Sahel. KNNV Publishing, Zeist, The Netherlands.

\section{Biographical sketches}

RUBEn Limiñana studies raptor ecology, particularly migration and wintering ecology of migratory raptors. BEATRIZ ARROYO's research interests include wildlife conservation and ecological conflicts related to human pressure on wildlife. JULIEN TERRAUBE is particularly interested in population ecology and conservation of threatened predators in ecosystems facing global changes. Michael McGrady has particular interests in demography, dispersal and ranging behaviour of birds of prey, with projects in Europe, Asia, North America, Africa and Central America. François Mougeot has broad interests in ecology, population dynamics and conservation. 